\title{
Stand structure and deadwood amount influences saproxylic fungal biodiversity in Mediterranean mountain unmanaged forests
}

\author{
Anna Maria Persiani (1), \\ Fabio Lombardi (2), \\ Dario Lunghini ${ }^{(1)}$, \\ Vito Mario Granito ${ }^{(1)}$, \\ Roberto Tognetti ${ }^{(3-4)}$, \\ Oriana Maggi (1), \\ Silvia Pioli ${ }^{(1)}$, \\ Marco Marchetti ${ }^{(3)}$
}

\begin{abstract}
Old-growth forests are key elements of ecosystem diversity and conservation strategies, providing niche differentiation and trophic pathways that produce structural and compositional heterogeneity. In these forests, deadwood is particularly important for saproxylic and mycorrhizal fungi, sustaining forest productivity and environmental services. In this study, the saproxylic fungal diversity in Mediterranean mountain forests, characterized by different management histories and forest types (holm oak and beech), was analyzed. The relationships between saproxylic fungal biodiversity and structural attributes were considered in three forest stands of the Apennines (Italy). In addition, descriptive environmental parameters and forest traits were related to prevailing fungal communities, in order to analyze the species composition and distribution patterns of saproxylic fungi resulting from the ordination processes. The study sites were selected on the basis of their late-serial stage of development. Species frequency was analyzed through multivariate techniques to test the relationships between fungi, structural attributes and environmental variables. A Detrended Correspondence Analysis (DCA) was used to investigate the response of the overall fungal community structure to environmental gradients. Living tree volume, altitude, vegetation type, and the frequency of species with ephemeral sporocarp lifespan played a crucial role in diversifying species distribution patterns. Deadwood volume and decay classes were related to taxonomic and trophic community diversity. However, differences between the considered climatic regions exerted a major role on the occurrence of fungi with ephemeral sporocarps more than deadwood abundance, utilized primarily as fructification substrate.
\end{abstract}

Keywords: Apennines Forests, Forest Biodiversity, Old-growth Forest, Saproxylic Fungi, Sporocarp Lifespan, Structural Heterogeneity linked to the forest structure: they can be used as a proxy of compositional and functional features and are more readily measurable than biological indicators. Attributes include the large variation in tree size, big old trees and multilayered forest canopy (Franklin \& Spies 1991).

Moreover, another typical criterion to identify old-growth traits is the presence of large amounts of standing and downed often used to define old-growth forests are

(1) Dipartimento di Biologia Ambientale, Sapienza Università di Roma, p.le Aldo Moro 5, I00185 Roma (Italy); (2) Department of Agronomy, Mediterranean University of Reggio Calabria, loc. Feo di Vito, 1-89060, Reggio Calabria (Italy); (3) Dipartimento di Bioscienze e Territorio, Università degli Studi del Molise, c.da Fonte Lappone, I-86090 Pesche (Italy); (4) EFI Project Centre on Mountain Forests (MOUNTFOR), v. Edmund Mach 1, I-38010 San Michele all'Adige (Italy)

@ Anna Maria Persiani (annamaria.persiani@uniroma1.it)

Received: Apr 03, 2014 - Accepted: Jun 29, 2015

Citation: Persiani AM, Lombardi F, Lunghini D, Granito VM, Tognetti R, Maggi O, Pioli S, Marchetti M (2015). Stand structure and deadwood amount influences saproxylic fungal biodiversity in Mediterranean mountain unmanaged forests. iForest 9: 115-124. - doi: 10.3832/ifor1304-008 [online 2015-09-08]

Communicated by: Giustino Tonon

deadwood in all stages of decay, considering that large standing dead trees and woody detritus on the forest floor include indirect evidence of canopy mortality and gap phase dynamics (Wirth et al. 2009, Lombardi et al. 2012, Herrero et al. 2013). Structural indicators are important tools that can be conveniently used to understand, assess and manage forest ecosystems (Fischer et al. 2009, Lassauce et al. 2011).

Old-growth forests are key elements in the strategies for biodiversity conservation. As a consequence of their high structural heterogeneity levels, they provide special habitats and trophic niches necessary for the existence and development of many species, such as birds, invertebrates, lichens, bryophytes and particularly saproxylic fungi (Harmon et al. 1986, Sippola \& Renvall 1999, Heilmann-Clausen 2001, Siitonen 2001, Humphrey et al. 2002, Jansson \& Andrén 2003, Nordén et al. 2007, Blasi et al. 2010, Persiani et al. 2010, Kraus \& Krumm 2013). In this sense, forest ecosystems with a high degree of naturalness could provide a reference for implementing sustainable forest management techniques for conservation purposes, as well as a tool for better understanding the role of forests in preser- 
ving ecosystem services.

Among attributes and indicators often used to label a forest as old growth, deadwood is one of the most typical (Harmon et al. 1986, Stokland et al. 2012). It plays significant roles in several ecological processes, creating the basis for cycling of photosynthetic energy, carbon, and nutrients stored in woody material (Holub et al. 2001, Laiho \& Prescott 1999), contributing to soil formation, development and protection. Deadwood is also a major component of ecosystem carbon storage and cycling (Tognetti \& Marchetti 2006). Moreover, deadwood was included within the list of carbon pools (above-ground and belowground biomass, litter, deadwood and soil) provided by Intergovernmental Panel on Climate Change (Penman et al. 2003), relevant for the estimation of carbon stocks and their changes under the UNFCCC and the Kyoto Protocol (Lasserre et al. 2006).

Beech (Fagus sylvatica L.) stands are crucially important forest ecosystems throughout the temperate and mountain areas of Europe (Nocentini 2009, Chiesi et al. 2013). Nevertheless, these ecosystems have been exploited by human activities for centuries and more recently have been affected by long-range air pollution (Paoletti \& Tuovinen 2011), with the result that old-growth and structurally complex forests with consistent amount of decomposing wood can be found only in protected areas and remote patches of the continent (Burrascano et al. 2013). In the Mediterranean Europe, important tree species will probably be negatively affected by the expected increase in climatic extreme (Marinšek et al. 2013) and associated disturbances in addition to direct changes in habitat quality (Hanewinkel et al. 2012). Holm oak (Quercus ilex L.), in particular, is relatively sensitive to the reduction of soil moisture content caused by climate change, especially in the southern part of Italy and along coastal areas (Attorre et al. 2011, Vitale et al. 2012). Currently, the importance of deadwood is emphasized for its function in the maintenance of biodiversity (Bradshaw et al. 2009), providing habitats for a plenty of organisms. If deadwood might be considered a key factor for biodiversity and functioning of these forests (Küffer et al. 2008), the same would apply to both saprotrophic and mycorrhizal fungi.

Fungi are known to be the principal wood decomposers in forest ecosystems and their activity makes deadwood available to other fungal species and wood-living organisms (Boddy 2001). In fact, wood-inhabiting fungi modify the necromass both chemically and structurally, and generate new habitats and food resources (Renvall 1995, Boddy 2001). Many researchers have studied the effect of forest management on saproxylic fungal communities, focusing on the effect of necromass reduction. The results of these studies converge to indicate that saproxylic fungal biodiversity de- creases in managed forests with impacts over the community composition (Küffer \& Senn-Irlet 2005b, Junninen et al. 2006, Müller et al. 2007, Bassler et al. 2012, Abrego \& Salcedo 2013). The amount and quality of deadwood, as well as the size and type of woody debris (in particular logs), and also the species, age and size of trees are structural attributes of forests that influence the saproxylic fungal community and its species richness (Nordén \& Paltto 2001, Heilmann-Clausen \& Christensen 2003, Odor et al. 2001, 2006, Junninen \& Komonen 2011, Lassauce et al. 2011).

Most of the studies conducted on forest management and deadwood influence on saproxylic fungi have focused on central and northern forest ecosystems of Europe, with some exceptions (e.g., Blasi et al. 2010, Persiani et al. 2010, Saitta et al. 2011, Abrego \& Salcedo 2011, Abrego \& Salcedo 2013, Granito et al. 2015). Therefore, there is the need to widen and integrate the current European guidelines for sustainable forestry, which are mostly based on data from boreal forests. In particular, it is important to test how wood inhabiting fungi respond to the structural attributes selected to assess the degree of forest naturalness. This indirect approach could be useful to comprehend the role of biodiversity, considering the complex relationships between saproxylic fungi and habitat traits (Christensen et al. 2004, Lasserre et al. 2010).

This study aims at analyzing saproxylic fungal biodiversity in Mediterranean mountain forests - namely three stands of central Apennines (Italy) - characterized by different management histories and tree species (holm oak and beech). The investigation has been focused on the relationships between saproxylic fungal biodiversity and some structural attributes that characterize the study areas (including substrate type, deadwood biomass and living trees volume). In addition, descriptive environmental parameters, forest traits and morphological/ecological traits of the species were studied for the characterization of fungal community, in order to analyze the species composition and the distribution patterns of saproxylic fungi resulting from the ordination processes. The study sites were selected on the basis of their late-serial stage of development.

\section{Material and methods}

\section{Study sites}

Two out of three of the study areas are located in the Cilento, Vallo di Diano e Alburni National Park (PNCVD), in southern Italy (Campania Region). The Park was recognized as a UNESCO World Heritage Site in 1998 and as a Biosphere Reserve in 1997. Litho-morphological landscape is characterized by gentle hills and calcareous mountains. The hilly landscape is mainly constituted of stratified flysch formations of Tertiary age, namely Flysch del Cilento, that is a complex and chaotic sedimentation of sandstone rich in quartz, feldspar, and mica and other minor components widespread near the hydrographical basin of the river Alento and mountains of western Cilento (Marchetti et al. 2010).

The PNCVD is characterized by two climatic regions (Temperate and Mediterranean - Mazzoleni et al. 1992, Rivas-Martìnez et al. 2002). The bioclimate is mainly oceanic, ranging from thermo-Mediterranean to supratemperate, with an ombroclimate ranging from dry to hyperhumid. According to climatic zones, litho-morphology and soil features, the vegetation potential ranges from dry coastal garrigue to holm oak woodlands, mixed forests of oak, hornbeam, and alder, beech forests, and highaltitude grasslands. The two study sites in the PNCVD ("Ottati" and "Corleto") are characterized by different ages of the oldgrowth forest. Particularly, the site of "Corleto" is a beech forest unmanaged since 1965, but still presenting the signs of past silvicultural activities. For example, the vertical and horizontal forest structure still reflects the past human activities, and stumps of artificial origin are evident. On the contrary, the "Ottati" study area is characterized by higher levels of naturalness (Marchetti et al. 2010), where the natural evolution has been in progress since decades. Marks of past human activities are scarce, considering that the stand is unmanaged since more than 170 years due to its difficult accessibility. The "Fonte Novello" site is located in the Venacquaro valley, in the Gran Sasso e Monti della Laga National Park (PNGSML), central Italy (Abruzzo Region). The study area is north facing, and the soils are classified as Lithic Rendolls, derived from the alteration of calcareous bedrocks. The territory falls within the temperate region, the bioclimate is oceanic while thermotype is inferior supratemperate and ombrotype is inferior humid (Blasi \& Michetti 2007). The vegetation of the Venacquaro Valley is dominated by beech forests. Particularly, the study area has not been subject to severe anthropogenic disturbances during the last centuries due to legal debates concerning the position of the administrative boundaries between Pietracamela and Fano Adriano municipalities.

\section{Experimental design}

A survey was conducted in spring and autumn 2012 on 3 plots, one for each site. The two sampling plots (ID51 and ID171) surveyed in the PNCVD were extracted from 22 separate forested areas considered as representative of the most common forest types in the Park. Detailed description of the survey design is reported in Corona et al. (2010) and in Marchetti et al. (2010). Each plot was previously defined as old-growth forest on the basis of stand structure and floristic information and former management history (Blasi et al. 2005, Rosati et al. 2005, Burrascano et al. 2009, 
Lombardi et al. 2010). However, based on the last attribute, the plots differed allowing the distinction between potentially old growth (labeled with POG in Tab. 1) and old growth (labeled with OG in Tab. 1). These stands have been subjected to forest harvesting and anthropogenic disturbances until 40 years ago. These two plots were delimited ( 0.25 ha square plots), and a buffer area of equivalent size adjacent to the plots was considered to better integrate the original datasets.

Moreover, the survey in the PNGSML, at the Fonte Novello (Fon) stand (Tab. 1), was realized on a 1-ha square plot; sampling was focused at the corners of the square plot, on a total of $0.36 \mathrm{ha}$. In this case, the buffer area was internal to the large plot, for a total surveyed area of 0.5 ha in order to have a similar sampling size.

\section{Deadwood classification}

Standing dead trees, downed dead trees, snags and stumps were measured when more than half base of their trunk was lying within the plot and buffer area. Coarse woody pieces were measured when more than half base of their thicker end was lying within the plot. A threshold height of $1.3 \mathrm{~m}$ was used to distinguish stumps $(<1.3 \mathrm{~m})$ from snags $(>1.3 \mathrm{~m})$. The position of each deadwood piece was obtained by measuring horizontal distances and azimuth from GPS points. The volume of standing and downed dead trees was estimated through volume equations ( $\mathrm{Ta}$ bacchi et al. 2011), while the volume of snags, stumps and coarse lying deadwood was assessed using the cone trunk model (eqn. 1):

$$
V=\pi \cdot \frac{h}{3} \cdot\left[\left(\frac{D}{2}\right)^{2}+\left(\frac{d}{2}\right)^{2}+\left(\frac{D}{2}\right) \cdot\left(\frac{d}{2}\right)\right]
$$

where $V$ is the volume $\left(\mathrm{m}^{3}\right), h$ is the height or length $(\mathrm{m}), D$ is the maximum diameter $(\mathrm{m}), d$ is the minimum diameter $(\mathrm{m})$. The minimum diameter considered was $5 \mathrm{~cm}$. Decay level classification of each deadwood piece was done following Hunter (1990). The surveyed deadwood components and attributes are detailed in Tab. 2.

\section{Inventory of saproxylic fungi}

Sporocarps of both Ascomycota and Basidiomycota were surveyed according to the sampling protocols used for similar studies in Europe (Bader et al. 1995, Siitonen 2001). Fungal intensive inventory was conducted at all the sites in late May and early June $(S$, spring) and October 2012 (A, autumn). All standing and downed deadwood with a minimum diameter of $10 \mathrm{~cm}$ was examined for the presence of fruit-bodies larger than $1 \mathrm{~mm}$ (Arnolds 1981). The nomenclature adopted was based on the Dictionary of the Fungi (Kirk et al. 2008) and the CABI Bioscience Database of Fungal Names found on internet - http://194.131.255.3/cabipages/ Names/names.asp?strGenus. The saproxylic fungi were described on the basis of their trophic role, as reported by various

Tab. 1 - Sampling sites in the central Apennines and their level of naturalness. (OG): old-growth; (POG): potentially old-growth), (physiognomy): type of forest; (Alt): altitude; (Exp): exposure; (DW): deadwood volumes ;(LT): total living tree volume.

\begin{tabular}{|c|c|c|c|c|c|c|c|c|}
\hline Plot & 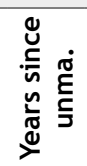 & 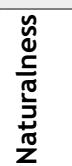 & Physiognomy & Site & $\begin{array}{c}\text { Alt. } \\
\text { (m a.s.l.) }\end{array}$ & $\operatorname{Exp}$ & $\begin{array}{c}\text { DW } \\
\left(\mathrm{m}^{3} / \mathrm{ha}\right)\end{array}$ & $\begin{array}{c}\mathrm{LT} \\
\left(\mathrm{m}^{3} / \mathrm{ha}\right)\end{array}$ \\
\hline ID51 & 175 & OG & & & & West & 44.26 & \\
\hline ID171 & 54 & POG & hilic be & Corl & 12 & N & 14.40 & 90 \\
\hline Fon & 300 & OG & microthermal beech & Pietracamela & 1340 & North & 89.00 & 1030.00 \\
\hline
\end{tabular}

authors (Arnolds 1981, Hendry et al. 1993, Arnolds et al. 1995, Whalley 1996, Boddy 2001, Lodge et al. 2004, Schwarze 2007). Furthermore, the persistency of their sporocarps was described (annual: occurring for nearly one year; perennial: living for a number of years; ephemeral: occurring for some days). The species were also subdivided in morphological groups according to the anatomical features of their sporocarps (see Tab. S1 in Appendix 1), as described by Heilmann-Clausen (2001).

\section{Statistical analyses}

Species frequency data (i.e., the occurrence of species at each plot) were analyzed by multivariate techniques to test the relationships between fungi, structural attributes and environmental variables. Detrended Correspondence Analysis (DCA) (Hill \& Gauch 1980), performed by Multivariate Analysis of Ecological Data using the software package PC-ORD, version 5.0 for Windows ${ }^{\oplus}$ (McCune \& Mefford 2006), was applied to investigate the response of the overall structure of the fungal communities to environmental gradients. The ordination axes of the DCA express similarities and dissimilarities in species composition between samples. DCA axes were rescaled with 26 segments.

The Mantel test was then performed by PC-ORD to test the hypothesis of independence between the community matrix and the variables (null hypothesis).

Pearson's correlations were then calculated using the software package SPSS (version 18.0, PASW Statistics for Windows,

Tab. 2 - Deadwood components surveyed in the study sites. $\left(D_{b h}\right)$ : diameter at breast height; $(H)$ : height; $(L)$ : length; $\left(D_{\min }\right)$ : minimum diameter; $\left(D_{\max }\right)$ : maximum diameter; $\left(D_{\text {base }}\right)$ : diameter at the base of the trunk; $\left(D_{\text {top }}\right)$ : diameter at the top of the trunk; (Origin): natural or artificial.

\begin{tabular}{|c|c|c|}
\hline $\begin{array}{l}\text { Deadwood } \\
\text { component }\end{array}$ & $\begin{array}{l}\text { Dimensional } \\
\text { thresholds }\end{array}$ & Assessed attributes \\
\hline $\begin{array}{l}\text { Standing dead } \\
\text { trees }\end{array}$ & $\mathrm{D}_{\mathrm{bh}} \geq 5 \mathrm{~cm} ; \mathrm{H} \geq 130 \mathrm{~cm}$ & $\begin{array}{l}\text { Species, } D_{\text {bh }}, H \text {, crown height, crown } \\
\text { projection on soil, decay class, position }\end{array}$ \\
\hline Snags & $\mathrm{D}_{\mathrm{bh}} \geq 5 \mathrm{~cm} ; \mathrm{H} \geq 130 \mathrm{~cm}$ & $\begin{array}{l}\text { Species, } D_{\text {base }}, D_{\text {top }} \text {, height, decay class, } \\
\text { position }\end{array}$ \\
\hline $\begin{array}{l}\text { Downed dead } \\
\text { trees }\end{array}$ & $D_{b h} \geq 5 \mathrm{~cm} ; \mathrm{H} \geq 130 \mathrm{~cm}$ & $\begin{array}{l}\text { Species, } D_{b h}, L \text {, crown insertion distance, } \\
\text { decay class, position, stem direction }\end{array}$ \\
\hline $\begin{array}{l}\text { Coarse woody } \\
\text { debris }\end{array}$ & $D_{\min } \geq 5 \mathrm{~cm} ; \mathrm{L} \geq 100 \mathrm{~cm}$ & $\begin{array}{l}\text { Species, } D_{\min }, D_{\max }, L \text {, decay class, position, } \\
\text { stem direction }\end{array}$ \\
\hline Stumps & $\mathrm{D}_{\text {top }} \geq 5 \mathrm{~cm} ; \mathrm{H}<130 \mathrm{~cm}$ & $\begin{array}{l}\text { Species, } D_{\text {base }}, D_{\text {top }} \text {, height, decay class, origin, } \\
\text { position }\end{array}$ \\
\hline
\end{tabular}

SPSS Inc., Chicago, IL, USA), in order to interpret the community gradient and to evaluate the relationships between ordination scores and ecological features, as well as structural attributes and environmental variables.

\section{Results}

\section{Structural attributes}

Forest structure strongly differed among the studied sites, showing progressively greater amounts of deadwood proportionally with increasing years since last intervention (Tab. 1). The old-growth plot of Fonte Novello was also characterized by high volumes of living trees. Conversely, Ottati (PNCVD) showed relatively high amounts of deadwood and a lower volume of living trees. All the studied stands revealed also a multimodal diameter distribution of living trees (data not shown). Ten diameter classes (with a range of $10 \mathrm{~cm}$ ) were detected over all the study sites, with a decreasing (though not regularly) frequency at the higher classes and a maximum diameter of $1.10 \mathrm{~m}$. The larger frequency of small size classes suggests the occurrence of canopy mortality and gap dynamics likely due to natural disturbances, such as wind or snow.

\section{Biodiversity of saproxylic fungi}

A total of 83 species of saproxylic fungi, including 13 Ascomycota and 70 Basidiomycota were detected in the three studied plots, in spring and autumn 2012 (see Tab. S1 in Appendix 1). 


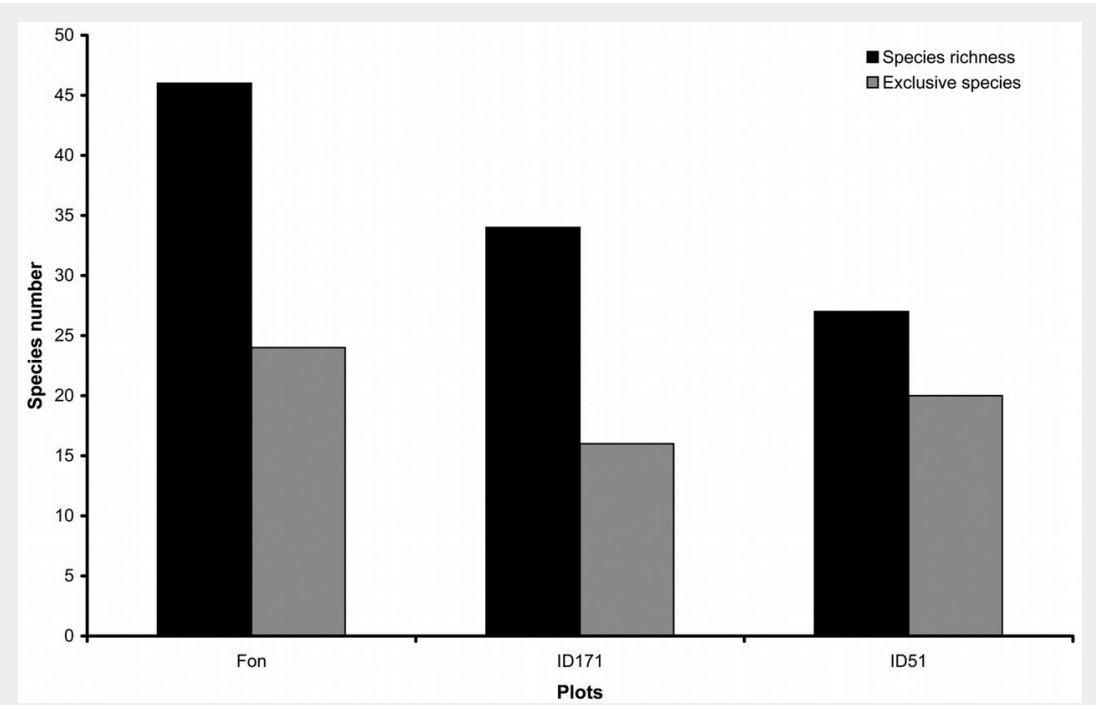

Fig. 1 - Total (spring and autumn) species richness and exclusive species found in the plots analyzed.

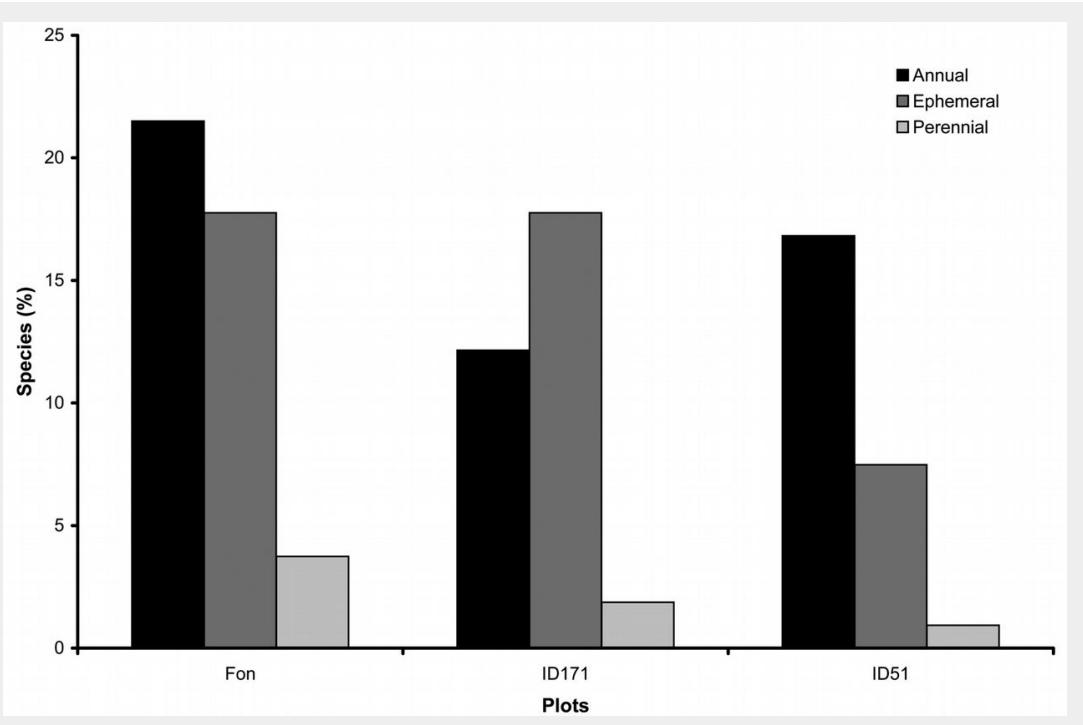

Fig. 2 - Total (spring and autumn) sporocarp types found in the plots analyzed.

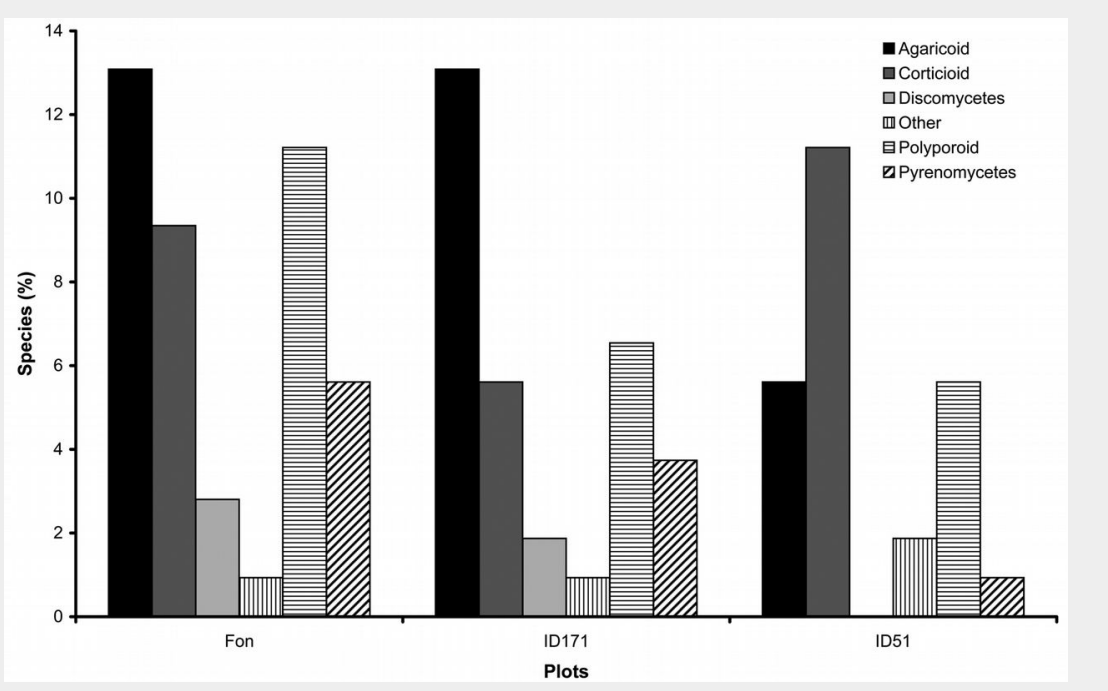

Fig. 3 - Total (spring and autumn) morphogroups found in the plots analyzed.
The most represented genera were Mycena with five species, Crepidotus, Phlebia, Pluteus and Trametes with four Phanerochaete, Polyporus and Stereum with three and Coprinellus, Diatrype, Ganoderma, Pholiota and Xylaria with two, while the remaining genera were represented by single species. The highest number of fungal species was recorded in Fonte Novello (Fon) that hosted 24 exclusive species, while in PNCVD, plots (ID171 and ID51) hosted 16 and 20 exclusive species, respectively (Fig. 1).

The species characterized by perennial sporocarps accounted for $7 \%$ of the total, species with annual sporocarps were $50 \%$, while ephemeral species accounted for the remaining $43 \%$ (Fig. 2). From a trophic point of view, $72 \%$ of the species belonged to the wood saprotrophs (Ws), while $28 \%$ were necrotroph parasites (Np). Agaricoid species were the most represented morphogroup in beech plots, while corticioid characterized the Quercus ilex stand (Fig. 3).

\section{Detrended Correspondence Analysis (DCA)}

To further investigate the variables affecting the distribution of fungi species, data were processed through DCA to assess the presence of underlying gradients (Fig. 4).

DCA results revealed two distinct community gradients, with an eigenvalue of 0.84 and 0.51 for Axis 1 and Axis 2, respectively, and gradient lengths of 6.29 and 3.30 SD units. These values confirmed a primary role of the gradient expressed by Axis 1 . Axis 2 still represented a distinct beta-diversity gradient, though containing less information. The third ordination axis was considerably weaker (eigenvalue: 0.15; gradient length: 2.58 SD units), thus it was not considered in further evaluation.

Two groups of plots were clearly identified in the DCA sorting space displayed in Fig. 4. The first group included the two oldgrowth plots represented in the two quadrants below axis 1 , while the other consisted of the potentially old-growth plot displayed in the quadrant above axis 1 .

\section{Mantel test}

The Mantel test was used to assess the hypothesis of independence between the community matrix and the variables (null hypothesis). The test yielded the following results: the observed $Z(3.15 \mathrm{E}+00)$ was larger than the expected $Z(2.91 \mathrm{E}+00)$; the standardized Mantel statistic $(r=0.79)$ was statistically significant $(p=0.002)$ based on the randomization test.

\section{Pearson's Correlation}

To obtain a complete interpretation of community gradients, a Pearson's correlation was performed between the scores on the DCA axes and some environmental and ecological parameters (Tab. 3). The results of the Pearson's correlation show that the gradient represented by DCA axis 1 was significantly and negatively related to living 
tree volume and altitude, and positively correlated with the vegetation type. DCA axis 1 was also significantly and negatively related to the frequency of species bearing short-lived fruit body. As regards to DCA axis 2, Pearson's correlation analysis revealed that it was significantly and negatively related to the total necromass volume and positively to forest management. Moreover, the studied plots were quite evenly distributed along the second axis, with the two-old-growth stands located in its lower part (Fig. 4), indicating that DCA axis 2 represents a remarkable environmental gradient. By contrast, no significant correlations were found with DCA axis 3.

\section{Discussion}

Relationship between fungal species and decomposition processes

The species found belong to 56 genera, which supports the hypotheses that fungal diversity is high in late-serial and oldgrowth forests. In the studied stands, the high fungal diversity and abundance was expected because of the reduced anthropic disturbance. Nevertheless, an analogous trend in fungal diversity was also observed by Wubet et al. (2012), which compared many European beech forest soils characterized by different management types. They found no differences in the fungal community structure, suggesting that soil fungal communities are region-specific, though composed of functionally diverse and complementary taxa. However, these site-specific studies suggest different patterns of co-existence in fungal diversity. In order to find a functional relationship between biotic and abiotic parameters and their association with forest management, a large-scale biogeographic approach should be conveniently applied.

Wood-inhabiting fungi abundance on coarse woody debris (CWD), showed that a consistent group of Ascomycota species, including Biscogniauxia nummularia (Bull.) Kuntze, Bisporella citrina (Batsch) Korf \&

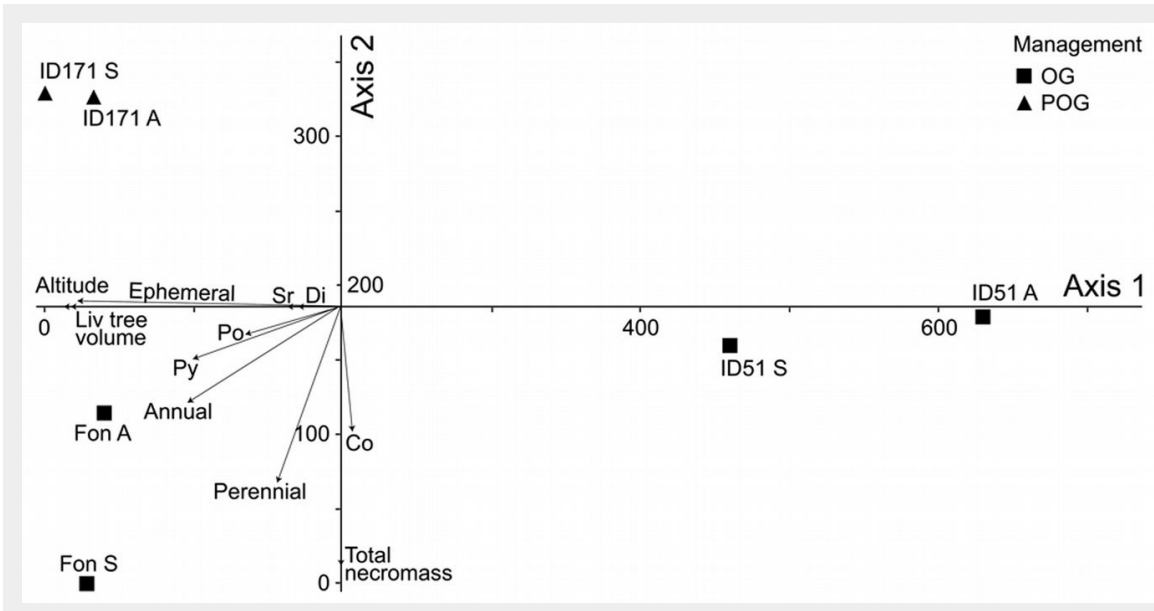

Fig. 4 - Results of the Detrended Correspondence Analysis. Axes are scaled in SD units x 100. (OG): Old Growth; (POG): Potentially Old Growth; (A): Autumn; (S): Spring.

S.E. Carp., Diatrype disciformis (Hoffm.) Fr., Hypoxylon fragiforme (Pers.) J. Kickx f., Kretzschmaria deusta (Hoffm.) P.M.D. Martin, Nemania serpens (Pers.) Gray, and Xylaria hypoxylon (L.) Grev., was associated with these plots.

Beside the above Ascomycota, it was noteworthy the occurrence in the Fonte Novello old-growth plot of Eutypa spinosa (Pers.) Tul. \& C. Tul., an indicator species of beech woodlands (Ainsworth 2004, Heilmann-Clausen 2001). Moreover, four Basidiomycota species such as Dentipellis fragilis (Pers.) Donk, Ganoderma pfeifferi Bres., Ischnoderma resinosum (Schrad.) P. Karst. and Phlebia nothofagi (G. Cunn.) Nakasone are reported among the 21 identified indicator species considered for the assessment of the conservation value of beech forests in Europe (Christensen et al. 2004). The occurrence of these four indicator species in this plot, in addition to $E$. spinosa, was not quantitatively comparable to other European beech forest sites of high conservation value (Heilmann-Clausen 2005). Nonetheless, this peculiarity implies a low to moderate conservation value for the Fonte Novello beech forest, although it might be relevant as compared with the plot ID171, where only two indicator species were hosted, Ceriporiopsis gilvescens (Bres.) Domanski and P. nothofagi.

$N$. serpens is the only Pyrenomycetes species found in plot ID51. Along the environmental gradient represented by the DCA axis 1 , beech stands were positioned at the opposite end compared with the holm oak plots. This could be due to the high content of tannins and other phenolic compounds in the bark of Quercus, as reported by Ciesla (2002). In fact, such compounds are implied in suberization processes and inhibit the growth of fungi as well as other microorganisms (Singh et al. 2010). Moreover, plot OD51 shares a number of species with beech stands, but also showed a certain degree of specificity, hosting 20 exclusive species (Fig. 1). Among those, it is worth noticing the occurrence of the taxon Phanerochaete, which includes typical Mediterranean species, such as $P$. martelliana (Bres.) J. Erikss. \& Ryvarden.

Furthermore, several environmental characteristics may explain the peculiarity of the plot ID51. It is located in the mid-upper hill belt at an altitude of $633 \mathrm{~m}$ a.s.l., and is

Tab. 3 - Pearson's correlation between DCA axes scores (Ax1-Ax3) and recorded variables. (LT): Living tree volume; (Tn): Total necromass; (Alt): altitude; (Sr): species richness; (Man): Management; (Veg): vegetation; (Seas): season; (Po): polyporoid; (Co): corticioid; (Py): pyrenomycetes; (Di): discomycetes; (Ag): agaricoid; (Ot): others; (Per): Perennial; (Eph): Ephemeral; (Ann): annual; $\left({ }^{*}\right)$ p <0.05; $(* *): p<0.01$.

\begin{tabular}{|c|c|c|c|c|c|c|c|c|c|c|c|c|c|c|c|c|}
\hline Variable & LT & Tn & Alt & $\mathrm{Sr}$ & Man & Veg & Seas & Po & Co & Py & $\mathrm{Di}$ & $\mathrm{Ag}$ & Ot & Per & Eph & Ann \\
\hline Ax1 & $-0.962^{* *}$ & -0.083 & $-0.976^{* *}$ & -0.390 & -0.515 & $0.834^{*}$ & 0.143 & -0.573 & 0.213 & -0.712 & -0.421 & -0.307 & -0.071 & -0.465 & $-0.948^{* *}$ & -0.724 \\
\hline$A \times 2$ & -0.063 & $-0.935^{* *}$ & 0.041 & 0.041 & $0.870^{*}$ & 0.397 & 0.188 & -0.315 & -0.656 & -0.424 & 0.001 & 0.096 & 0.056 & -0.779 & 0.151 & -0.575 \\
\hline$A \times 3$ & 0.438 & -0.172 & 0.469 & -0.300 & 0.438 & -0.303 & -0.565 & -0.065 & -0.802 & -0.091 & -0.214 & -0.375 & -0.507 & 0.043 & 0.483 & 0.206 \\
\hline LT & - & 0.272 & $0.994^{* *}$ & 0.462 & 0.354 & $-0.935^{* *}$ & 0 & 0.674 & -0.070 & $0.830^{*}$ & 0.500 & 0.406 & 0.140 & 0.633 & $0.969^{* *}$ & 0.802 \\
\hline Tn & - & - & 0.166 & 0.262 & -0.804 & -0.595 & 0 & 0.606 & 0.688 & 0.596 & 0.318 & 0.194 & 0.203 & $0.917^{* *}$ & * 0.056 & 0.733 \\
\hline Alt & - & - & - & 0.444 & 0.453 & $-0.891^{*}$ & 0 & 0.622 & -0.149 & 0.784 & 0.476 & 0.394 & 0.120 & 0.545 & $0.987^{* *}$ & 0.739 \\
\hline $\mathrm{Sr}$ & - & - & - & - & 0.031 & -0.482 & 0.700 & $0.876^{*}$ & 0.515 & 0.632 & $0.993^{* *}$ & ${ }^{*} 0.977^{* *}$ & $0.943^{* *}$ & 0.402 & 0.417 & 0.446 \\
\hline Veg & - & - & - & - & - & - & 0 & -0.785 & -0.195 & $-0.913^{*}$ & -0.535 & -0.410 & -0.191 & $-0.866^{*}$ & $-0.830^{*}$ & $-0.939^{* *}$ \\
\hline Seas & - & - & - & - & - & - & - & 0.376 & 0.424 & 0.233 & 0.655 & $0.828^{*}$ & 0.781 & 0 & 0.070 & -0.153 \\
\hline Po & - & - & - & - & - & - & - & - & 0.532 & $0.821^{*}$ & $0.912^{*}$ & 0.793 & 0.729 & 0.766 & 0.544 & 0.806 \\
\hline Py & - & - & - & - & - & - & - & - & - & - & 0.640 & 0.592 & 0.400 & $0.823^{*}$ & 0.721 & $0.872^{*}$ \\
\hline $\mathrm{Di}$ & - & - & - & - & - & - & - & - & - & - & - & $0.957^{* *}$ & $0.920^{* *}$ & 0.463 & 0.443 & 0.502 \\
\hline $\mathrm{Ag}$ & - & - & - & - & - & - & - & - & - & - & - & - & $0.938^{* *}$ & 0.324 & 0.396 & 0.323 \\
\hline Per & - & - & - & - & - & - & - & - & - & - & - & - & - & - & 0.446 & $0.922^{* *}$ \\
\hline
\end{tabular}


characterized by thermophilous sclerophyllous vegetation, and well adapted to seasonal water availability fluctuations. Unlike the other two plots settled in the lower mountain belt, it has a very pronounced slope (55\%) facing south-southwest, where xeric conditions are more frequent. Precipitation and temperature influence vegetation, and consequently soil properties, by affecting the type and rates of chemical, mineralogical, biological, and physical processes. Indeed, field experiments on soil warming have highlighted the sensitivity of decomposition process to temperature (Allison et al. 2010), which affects carbon sequestration and cycling, and consequently the level of biodiversity. Mean annual temperature has been indicated as one of the main drivers of CWD decay rates (Mackensen et al. 2003). Recently, Bradford et al. (2014) has shown that local-scale factor influence more than climate the microbial activity and, consequently, the decomposition of deadwood.

\section{DCA and Pearson's correlation}

\section{Axis 1}

DCA revealed a relatively high variation among plots along the first axis, that represents an important ecological gradient of differentiation among plots. As revealed by the Pearson's correlation analysis carried out, living tree volume, altitude, vegetation, and the frequency of species with ephemeral sporocarp lifespan played a crucial role in diversifying species distribution patterns. Differences in CWD quality among stands may be due to different vegetation types and local microclimate, thus explaining the diverse arrangement of the plots along the DCA axes.

The beech forest plots located at higher altitudes were positioned on the left side along DCA axis 1, whereas the holm oak forest plot ID51 (both autumnal and spring inventories) was positioned on the far right of the same axis. Plot ID51 differed considerably from the other two plots, as it is settled at an altitude lower than any other plots considered in this study.

There is a scarcity of specific studies and consistent results concerning the relationships between elevation and wood-inhabiting fungi. Pouska et al. (2010) outlined how elevation gradients and structural attributes might underlie and drive the shifts in species richness and composition patterns of saproxylic fungi. Sequences of fungal diversity along altitudinal gradients, enabling correlations of measured decay mechanisms with climate spatial variability (including altitude, exposure and slope), warrant further studies.

The investigated structural attributes, such as deadwood and living tree volume, represent some of the functional aspects of the old-growth forests providing special ecosystem values (Marchetti et al. 2010). In the surveyed forests, the long-time absence of logging led to an uneven-aged stand structure, although the effect of past management still influences the current structure of all sites. The heterogeneity of stands increased due to the occurrence of developmental gaps, probably related to small-scale disturbances, such as strong wind and heavy snow. It is likely that this feature influenced also the occurrence and diversity of wood-inhabiting fungi, as a consequence of the different microclimatic conditions on the forest floor. The living volume was significantly higher than in corresponding managed forests types (Marchetti et al. 2010), indicating that the occurrence of natural disturbances, rather than silvicultural practices, did not affect the overall forest productivity.

Differences between the considered climatic regions affects the occurrence of fungi with ephemeral sporocarps more than deadwood abundance, utilized primarily as fructification substrate. Moreover, based on the negative correlation of DCA axis 1 with the ephemeral sporocarp lifespan characteristics, we may infer that species with short-lived sporocarps displayed greater diversity, reflecting intra-annual climate variability (Berglund et al. 2005), and variation in bioclimatic conditions.

The highly similar positioning in the DCA space of the two seasonal samplings from the same plots indicated that each stand has a specific fungal community based upon the presence of persistent species, on annual basis. The major drivers of such communities are ascribable to vegetation types, but also to differences between the considered climatic regions. This finding confirm that the composition of the woodinhabiting macrofungal community is related to the stand type, as shown by Gates et al. (2011). Heilmann-Clausen (2001) also found that a pronounced shift in community structure could be driven by a complex gradient, including microclimate condition and decay rate, resulting in the diversification of CWD quality and classes.

\section{Axis 2}

The plot distribution along the DCA axis 2 may be interpreted as a response to a decreasing gradient of CWD availability ( $r=$ -0.935; $p<0.01$ ), also influenced by past forest harvesting. In fact, DCA axis 2 was also positively correlated with the management variable $(r=0.870, p<0.05)$. Lindblad (1998) showed that species richness of fruiting wood-inhabiting fungi was negatively affected by forest management and found higher species richness in decayed logs in a natural forest than similar logs in a managed forest.

As a consequence of the lower CWD availability, plots in the lower part of the DCA ordination space are expected to be characterized by a particular group of fungal species. This was the case of the plot in Fonte Novello, where species with perennial fruit body, such as Fomes fomentarius (L.) J. Kickx f., Fomitopsis pinicola (Sw.) P.
Karst. and Ganoderma pfeifferi Bres. accounted for $57 \%$ of the total perennial species collected.

The strong relevance of the aforementioned polyporoid species agreed with the results obtained by Bader et al. (1995) and Sippola et al. (2004), which found that polyporoid species richness was related to the amount and quality of CWD. Likewise, high amounts of CWD, deadwood quality and the co-occurrence of diverse decay stages are among the ecological requirements of saproxylic fungal species, as demonstrated in a number of studies conducted in central and northern Europe (Renvall 1995, Dämon 2001, Nordén et al. 2004, Küffer \& Senn-Irlet 2005a). The deadwood volume was previously considered an important variable in predicting species richness of several groups of species associated with deadwood habitats (Penttilä et al. 2004), but also a criterion to identify old-growth conditions (Lombardi et al. 2010) and a tool to understand the evolution phase of forests with low anthropic disturbances (Marchetti \& Lombardi 2006, Lombardi et al. 2010). Particularly, deadwood volume was varying among the investigated stands, reflecting the past management legacy and the small-scale disturbance regime. These results were in accordance with a former study conducted within the PNCVD (Persiani et al. 2010), which demonstrated how deadwood volume affected trophic roles and species diversity of saproxylic organisms in oldgrowth forests, including wood-inhabiting fungi.

The amount of deadwood observed in the study sites were significantly lower than those found in recently established reserves (reviewed by Christensen et al. 2005), indicating a mean value of deadwood volume equal to $130 \mathrm{~m}^{3} \mathrm{ha}^{-1}$.

The successional stage of each stand, the recent forest history and the disturbance regime can be considered as the main factors explaining the variation in deadwood amount observed in the investigated forests. Obviously, the amount of naturally occurring deadwood may have been reduced by the frequent collection of firewood by local people. Nonetheless, from a quantitative standpoint lying deadwood constituted the most significant deadwood component in the developmental phases close to old-growthness. Coarse woody debris and downed dead trees were the consequence of natural mortality occurring in the stands due to the natural processes established in the studied forests in the last decades. In our study sites, current mortality is mainly related to endogenous processes, such as competition, but also wind and heavy snow falls.

Although the investigated forests have been unmanaged for decades, signs of past removal of deadwood are still evident, and this was probably the reason why the deadwood in the most advanced decay classes was not frequent. Indeed, in Me- 
diterranean ecosystems deadwood could decay five times faster than in other climatic regions (Lombardi et al. 2011). Therefore, the deadwood volumes occurring in the investigated forests did not necessarily indicate the presence of higher anthropic disturbance regimes. The presence of different decay stages in the examined stands supports the hypothesis that many saproxylic species occur in these forests, explaining the wood-inhabiting fungal richness.

\section{Correlation of biological and structural variables}

In this study, a high correlation was found between living tree volume and Pyrenomycetes morphogroup ( $r=0.830 ; p<0.05)$. Among the Pyrenomycetes collected, B. nummularia, $E$. spinosa, $K$. deusta showed necrotrophic attitude. These fungi would be considered either endophytes on the trunks or latent invaders (Boddy \& Rayner 1983, Boddy 2001, Parfitt et al. 2010). On the other hand, the correlation analysis revealed a very significant relationships of living tree volume with ephemeral sporocarps $(r=0.969 ; p<0.01)$ and of the total necromass volume with perennial sporocarps $(r=0.917 ; p<0.01)$. These correlations might reflect a selected functional crossconnection between wood-decomposer fungal species and guild of mycorrhizal fungal species associated to living trees, occurring as active webs of extra radical hyphae in the soil, named "The WoodWide-Web" (Simard et al. 1997) referring to plant-to-plant carbon transfer throughout a common mycorrhizal network.

Martin \& Nehls (2009) explored the ecological aspects of ectomycorrhizal fungi from a genomics perspective in a French forest, and obtained evidence about the dominance of Agaricomycetes in the soil, including a large number of ectomycorrhizal species (EM). These results confirmed that EM fungi could be characterized by a dual lifestyle, living as symbiont with plant roots and as facultative saprotrophs in the soil. Ogura-Tsujita et al. (2009) reported that Mycenaceae species are mycorrhizal of any plants and not exclusively of orchids, as previously reported for several Mycena species (Xu \& Fan 2001). Mycenaceae fungi are known as saprotrophic free living-litter and wood decomposers (Cannon \& Kirk 2007). In our study, the genus Mycena was represented with five species, usually occurring on wood in advanced decay stages. This evidence highlights the role of fungi in the nutrient and energy transport, connecting patches of different resources in the ecosystem (Dighton 2003), and support the high correlation observed between living tree volume and ephemeral sporocarps.

In this study, the high correlation observed between deadwood volume and perennial sporocarps, confirms the pivotal role in the wood decay process of a wide range of wood-rotting fungi, characterized by perennial sporocarps. The presence of large amounts of deadwood in forest ecosystems, and particularly in old-growth forests, has often been connected with high volume of living biomass (Spies 2004). However, this relationship did not emerge from the correlation analysis carried out in this study. Nevertheless, Burrascano et al. (2013) reported that old-growth forests host significantly higher amounts of living biomass than mature forests. In this sense, the presence of large living trees would be an important indicator of late successional forest structure; in particular, a minimum of 30 large living trees per hectare with diameter at breast height larger than 50 $\mathrm{cm}$ might be considered a suitable threshold density (Burrascano et al. 2013).

A lack of correlation between deadwood volume and living tree biomass in temperate broadleaved forests suggest that stand age and management, which also affect basal area and tree biomass, preclude the use of living biomass as a predictive variable of deadwood (Nordén et al. 2004). However, it might be possible that correlations between living and deadwood biomass only emerge for stands with live tree stocking exceeding a certain threshold and/or when stands are experiencing selfthinning (Woodall \& Westfall 2009). When stands are under-stocked with a low number of small-sized trees, deadwood resources may be unpredictable and tree mortality may be a significant contributor of deadwood. Woodall \& Westfall (2009) found that the lowest levels of deadwood stocking were in stands with moderate levels of live tree stocking. Other studies showed that living tree volume alone failed to describe old-growth forest structure due to the high variation in tree size typical of these ecosystems (Marchetti et al. 2010).

Disturbance or self-thinning inducing tree mortality is the only way for deadwood stocking to increase, with live tree stocking shifting to either low or high levels. Deadwood accretion factors (e.g., disturbance, self-thinning, and senescence) would increase deadwood stocking in stands with high or low live tree stocking (Woodall \& Westfall 2009). This trend is shared by forests growing at high altitudes or latitudes (e.g., northern Europe or Alpine environments), where a more frequent incidence of windstorm-damages and natural disturbances, such as wind and ice storms, might explain the higher amount of deadwood generally reported in these contexts (Peterken 1996). Traditional harvest processes would reduce deadwood stocking in all forest stands, while decay progression diminishes deadwood amounts, especially in forests of temperate and warm climates. For example, the Mediterranean regions, with erratic precipitation regimes and temperature patterns, are generally characterized by faster decomposition rates due to higher temperatures when compared with northern Europe (Hahn \& Christensen 2004). However, no simple deadwood sto- cking recommendations can be applied, due to the inherent complexity of all the stand, site, and management factors that drive deadwood dynamics.

\section{Conclusion}

This paper provides a contribution to the analysis of saproxylic fungal biodiversity in relation to stand structural attributes in Mediterranean mountainous forests characterized by different management histories. Living tree volume, altitude, vegetation, and the frequency of species with ephemeral sporocarp lifespan played a crucial role in diversifying species distribution patterns. Particularly, the increase of the stand structural heterogeneity, related to the timespan from last management activities and to small-scale disturbances, deeply affects the occurrence and the diversity of wood-inhabiting fungi, as a consequence of the different microclimates occurring on the forest floor. The amount of deadwood at the study sites were related to the taxonomic and functional diversity of saproxylic organisms, including wood-inhabiting fungi, which were influenced by the deadwood volume and decay classes, according to decomposition processes (Ódor et al. 2006, Küffer et al. 2008).

High CWD volumes and large living tree densities in old-growth forests influence the provision of habitat for ecologically important saproxylic organisms, thus supporting high levels of late-successional biodiversity. The study of old-growth and semi-natural forests was proved useful as reference tool to implement rehabilitation criteria in sustainable management, to maintain and increase biodiversity and other ecosystem services provided by managed forests. Forest management should mimic the natural thinning dynamics, increasing the amount of dead trees and the diversification of the vertical and horizontal tree layers, considering the good potential for restoring and increasing the diversity of saproxylic communities and their associated ecological functions.

\section{References}

Abrego N, Salcedo I (2011). How does fungal diversity change based on woody debris type? A case study in Northern Spain. Ekologija 57: 109-119. - doi: 10.6001/ekologija.v57i3.1916

Abrego N, Salcedo I (2013). Variety of woody debris as the factor influencing wood-inhabiting fungal richness and assemblages: Is it a question of quantity or quality? Forest Ecology and Management 291: 377-385. - doi: 10.1016/ j.foreco.2012.11.025

Ainsworth AM (2004). Developing tools for assessing fungal interest in habitats. 1: Beech woodland saprotrophs. English Nature Research Reports 597: 1-75.

Allison SD, Wallenstein MD, Bradford MA (2010). Soil-carbon response to warming dependent on microbial physiology. Nature Geoscience 3: 336-340. - doi: 10.1038/ngeo846

Arnolds E (1981). Ecology and coenology of macrofungi in grasslands and moist heatlands 
in Drenthe, the Netherlands. Part1. Introduction and synecology. Bibliotheca Mycologica 83, Cramer J, Vaduz, Liechtenstein, pp. 407.

Arnolds E, Kuyper ThW, Noordeloos EM (1995). Overzicht van de paddestoelen in Nederland [Overview of mushrooms in the Netherlands]. Nederlandse Mycologische Vereniging, Wijster, the Netherlands, pp. 872. [in Dutch]

Attorre F, Francesconi F, Valenti R, Vitale M, Alfò $M$, Bruno $F$ (2011). Evaluating the effects of climate change on Italian forests trough abundance measures and species composition indexes. Applied Vegetation Science 14: 242-255. doi: 10.1111/j.1654-109X.2010.01114.x

Bader P, Jansson S, Jonsson BG (1995). Woodinhabiting fungi and substratum decline in selectively logged boreal spruce forests. Biological Conservation 72: 355-362. - doi: 10.1016/ 0006-3207(94)00029-P

Bassler C, Muller J, Svoboda M, Lepsova A, Hahn C, Holzer H, Pouska V (2012). Diversity of wooddecaying fungi under different disturbance regimes - a case study from spruce mountain forests. Biodiversity and Conservation 21: 3349. - doi: 10.1007/s10531-011-0159-0

Berglund H, Edman M, Ericson L (2005). Temporal variation of wood-fungi diversity in boreal old-growth forests: implications for monitoring. Ecological Applications 15: 970-982. - doi: 10.1890/04-0628

Blasi C, Michetti L (2007). Biodiversity and climate. In: "Biodiversity in Italy" (Blasi C, Boitani L, La Posta S, Manes F, Marchetti M eds). Palombi Editore, Rome, Italy, pp. 57-66.

Blasi C, Rosati L, Di Pietro R, Marchetti M, Marignani M (2005). Variazioni cenologiche e stima della diversità floristica dei boschi a Quercus cerris del flysch del Cilento in relazione al tipo di gestione selvicolturale [Coenological variation and floristic diversity assessment in relation to forest management in Quercus cerris woods of turbiditic substrata of Cilento National Park]. Italia Forestale e Montana 60: 387-404. [in Italian]

Blasi C, Marchetti M, Chiavetta U, Aleffi M, Audisio P, Azzella MM, Brunialti G, Capotorti G, Del Vico E, Lattanzi E, Persiani AM, Ravera S, Tilia A, Burrascano S (2010). Multi-taxon and forest structure sampling for old-growth indicators identification and forest monitoring. Plant Biosystems 144: 160-170. - doi: 10.1080/112635009 03560538

Boddy L (2001). Fungal community, ecology and wood decomposition processes in angiosperms: from standing tree to complete decay of coarse woody debris. Ecological Bulletins 49: 43-56. [online] URL: http://www.jstor.org/sta ble/20113263

Boddy L, Rayner ADM (1983). Origins of decay in living deciduous trees: the role of moisture content and a re-appraisal of the expanded concept of tree decay. New Phytologist 94: 623-641. - doi: 10.1111/j.1469-8137.1983.tb04871.x Bradford MA, Warren IIRJ, Baldrian P, Crowther TW, Maynard DS, Oldfield EE, Wieder WR, Wood SA, King JR (2014). Climate fails to predict wood decomposition at regional scales. Nature Climate Change. - doi: 10.1038/nclimate 2251

Bradshaw CJA, Warkentin IG, Sodhi NS (2009). Urgent preservation of boreal carbon stocks and biodiversity. Trends in Ecology and Evolution 24: 541-548. - doi: 10.1016/j.tree.2009.03. 019

Burrascano S, Rosati L, Blasi C (2009). Plant species diversity in Mediterranean old-growth forests: a case study from central Italy. Plant Biosystems 143: 190-200. - doi: 10.1080/112635 00802709699

Burrascano S, Keeton WS, Sabatini FM, Blasi C (2013). Commonality and variability in the structural attributes of moist temperate old-growth forests: a global review. Forest Ecology and Management 291: 458-479. - doi: 10.1016/j.for eco.2012.11.020

Cannon PF, Kirk PM (2007). Fungal families of the world. CABI Publishing, Wallingford, UK, pp. 456. [online] URL: http://books.google. com/books?id=Lw1VLSHoxnAC

Chiesi M, Maselli F, Chirici G, Corona P, Lombardi F, Tognetti R, Marchetti M (2013). Assessing most relevant factors to simulate current annual increments of beech forests in Italy. iForest 7: 115-122. - doi: 10.3832/iforo943-007

Christensen M, Heilmann-Clausen J, Walleyn R, Adamcik S (2004). Wood-inhabiting fungi as indicators of nature value in European beech forests. In: "Monitoring and Indicator of Forest Biodiversity in Europe. From Ideas to Operationality" (Marchetti M ed). EFI Proceedings 51: 229-237.

Christensen M, Hahn K, Mountford EP, Odor P, Standovar T, Rozenbergar D, Diaci J, Wijdeven S, Mayer P, Winter S, Vrska T (2005). Deadwood in European beech (Fagus sylvatica) forest reserves. Forest Ecology and Management 210: 267-282. - doi: 10.1016/j.foreco.2005.02.032 Ciesla WM (2002). Non-wood forest products from temperate broad-leaved trees. Non-Wood Forest Products 15, FAO Technical Papers, Rome, Italy, pp. 125. [online] URL: http:// books.google.com/books?id=yDoE8-8YPwsC

Corona P, Blasi C, Chirici G, Facioni L, Fattorini L, Ferrari B (2010). Monitoring and assessing oldgrowth forest stands by plot sampling. Plant Biosystems 144: 171-179. - doi: 10.1080/112635 00903560710

Dämon W (2001). Die corticioiden Basidienpilze des Bundeslandes Salzburg (Österreich) [The corticioid Basidiomycetes of the province of Salzburg (Austria)]. Floristik, Lebensräume und Substratökologie. Bibliotheca Mycologica 189: 1-413. [in German]

Dighton J (2003). Fungi in ecosystem processes. Marcel Dekker, New York, USA, pp. 432.

Fischer R, Granke O, Chirici G, Meyer P, Seidling W, Stofer S, Corona P, Marchetti M, Travaglini $D$ (2009). Background, main results and conclusions from a test phase for biodiversity assessments on intensive forest monitoring plots in Europe. iForest 2: 67-74. - doi: 10.3832/iforo493002

Franklin JF, Spies TA (1991). Composition, function, and structure of old-growth Douglas-fir forests. In: "Wildlife and vegetation of unmanaged Douglas-fir forests" (Ruggiero LF, Aubry KB, Carey AB, Huff MH eds). Gen. Tech. Rep. PNW-GTR-285, USDA Forest Service, Portland, OR, USA, pp. 91-110. [online] URL: http:// courses.washington.edu/esrm315/pdfs/Franklin Spies1991b.pdf

Gates G, Mohammed C, Wardlaw T, Ratkowsky
DA, Davidson NJ (2011). The ecology and diversity of wood-inhabiting macrofungi in a native Eucalyptus oblique forest of southern Tasmania, Australia. Fungal Ecology 4: 56-67. - doi: 10.1016/j.funeco.2010.07.005

Granito VM, Lunghini D, Maggi O, Persiani AM (2015). Wood-inhabiting fungi in southern Italy forest stand: morphogroups, vegetation types and decay class. Mycologia [in press] - doi: $10.3852 / 13-400$

Hahn K, Christensen M (2004). Dynamics of deadwood in European beech forests in relation to natural disturbances. Rit Mogilsar Rannsoknastodvar Skogræktar, Iceland Forest Research Bullettin 22: 5-8.

Hanewinkel M, Cullmann DA, Schelhaas MJ, Nabuurs GJ, Zimmermann NE (2012). Climate change may cause severe loss in the economic value of European forest land. Nature Climate Change 3: 203-207. - doi: 10.1038/nclimate1687 Harmon ME, Franklin JF, Swanson FJ, Sollins P, Gregory SV, Lattin JD, Anderson NH, Cline SP, Aumen NG, Sedell JR, Lienkaemper GW, Cromack Jr K, Cummins KW (1986). Ecology of coarse woody debris in temperate ecosystem. Advances in Ecological Research 15: 133-302. doi: 10.1016/S0065-2504(08)60121-X

Heilmann-Clausen J (2001). A gradient analysis of communities of macrofungi and slime moulds on decaying beech logs. Mycological Research 105: 575-596. - doi: 10.1017/So953756201003665 Heilmann-Clausen J (2005). Diversity of saproxylic fungi on decaying beech wood in protected forests in the county of Halland. Meddelande 2005:7, Länsstyrelsen Halland, Sweden, pp. 64.

Heilmann-Clausen J, Christensen M (2003). Fungal diversity on decaying beech logs - implications for sustainable forestry. Biodiversity Conservation 12: 953-973. - doi: 10.1023/A:1022825 809503

Hendry SJ, Boddy L, Lonsdale D (1993). Interactions between callus cultures of European beech, indigenous ascomycetes and derived fungal extracts. New Phytologist 123: 421-428. doi: 10.1111/j.1469-8137.1993.tb03753.x

Herrero C, Krankina O, Monleon VJ, Bravo F (2013). Amount and distribution of coarse woody debris in pine ecosystems of northwestern Spain, Russia and the United States. iForest 7: 53-60. - doi: 10.3832/iforo644-007 Hill MO, Gauch HG (1980). Detrended correspondence analysis: an improved ordination technique. Vegetatio 42: 47-58. - doi: $10.1007 / B F$ 00048870

Holub SM, Spears JDH, Lajtha K (2001). A reanalysis of nutrient dynamics in coniferous coarse woody debris. Canadian Journal of Forest Research 31: 1894-1902. - doi: 10.1139/x01-125 Humphrey JW, Davey S, Peace AJ, Ferris R, Harding $K$ (2002). Lichens and bryophyte communities of planted and semi-natural forests in Britain: the influence of site type, stand structure and deadwood. Biological Conservation 107: 165-180. - doi: 10.1016/S0006-3207(02)00057-5 Hunter ML (1990). Wildlife, forests, and forestry: principles of managing forests for biological diversity. Prentice Hall, Englewood Cliffs, NJ, USA, pp. 370. [online] URL: http://www.cab direct.org/abstracts/19910654124.html

Jansson G, Andrén H (2003). Habitat composi- 
tion and bird diversity in managed boreal forests. Scandinavian Journal of Forest Research 18: 225-236. - doi: 10.1080/02827581.2003.97282 93

Junninen K, Komonen A (2011). Conservation ecology of boreal polypores: a review. Biological Conservation 144: 11-20. - doi: 10.1016/j.bio con.2010.07.010

Junninen $K$, Simila $M$, Kouki J, Kotiranta $H$ (2006). Assemblages of wood inhabiting fungi along the gradients of succession and naturalness in boreal pine-dominated forests in Fennoscandia. Ecography 29: 75-83. - doi: 10.1111/ j.2005.0906-7590.04358.x

Kirk PM, Cannon PF, Minter DW, Stalpers JA (2008). Dictionary of the Fungi $\left(10^{\text {th }}\right.$ edn). CABI Publishing, Wallingford, UK, pp. 771.

Kraus D, Krumm F (2013). Integrative approaches as an opportunity for the conservation of forest biodiversity. European Forest Institute, Freiburg, Germany, pp. 284.

Küffer N, Senn-Irlet B (2005a). Influence of forest management on the species richness and composition of wood-inhabiting basidiomycetes in Swiss forests. Biodiversity Conservation 14: 2419-2453. - doi: 10.1007/s10531-0040151-z

Küffer N, Senn-Irlet B (2005b). Diversity and ecology of wood-inhabiting aphyllophoroid basidiomycetes on fallen woody debris in various forest types in Switzerland. Mycological Progress 4: 77-86. - doi: 10.1007/s11557-006-0110-z Küffer N, Gillet F, Senn-Irlet B, Aragno M, Job D (2008). Ecological determinants of fungal diversity on dead wood in European forests. Fungal Diversity 30: 83-95. [online] URL: http:// hal.archives-ouvertes.fr/hal-00357745/

Laiho R, Prescott CE (1999). The contribution of coarse woody debris to carbon, nitrogen, and phosphorus cycles in three Rocky Mountain coniferous forests. Canadian Journal of Forest Research 29 (10): 1592-1603. - doi: 10.1139/x99132

Lassauce A, Paillet $\mathrm{Y}$, Jactel $\mathrm{H}$, Bouget C (2011). Deadwood as a surrogate for forest biodiversity: meta-analysis of correlations between deadwood volume and species richness of saproxylic organisms. Ecological Indicators 11: 1027-1039. - doi: 10.1016/j.ecolind.2011.02.004

Lasserre B, Marchetti M, Tognetti R (2006). Problems in the inventory of the belowground forest biomass carbon stocks. Forest@3 (4): 542-554. [in Italian with English summary] - doi: 10.3832/eforo415-0030542

Lasserre B, Motta E, D'Amico L, Scirè M, Marchetti $M$ (2010). Using the Resistograph ${ }^{\circledR}$ to distinguish different types of wood rot on living silver fir in Molise (Italy). Forest@ 7: 190198. [in Italian with English summary] - doi: 10.3832/eforo638-007

Lindblad I (1998). Wood-inhabiting fungi on fallen logs of Norway spruce: Relations to forest management and substrate quality. Nordic Journal of Botany 18: 243-255. - doi: 10.1111/j. 1756-1051.1998.tbo1877.x

Lodge DJ, Ammirati JF, O'Dell TE, Mueller GM, Huhndorf SM, Wang CJ (2004). Terrestrial and lignicolous macrofungi. In: "Biodiversity of fungi: Inventory and Monitoring Methods" (Mueller GM, Bills GF, Foster MS eds). Elsevier, Academic Press, London, UK, pp. 127-172. [online] URL: https://moodle.ufsc.br/pluginfile. php/1311301/

Lombardi F, Chirici G, Marchetti M, Tognetti R, Lasserre B, Corona P, Barbati A, Ferrari B, Di Paolo S, Giuliarelli D, Mason F, lovino F, Nicolaci A, Bianchi L, Maltoni A, Travaglini D (2010). Deadwood in forest stands close to oldgrowthness under Mediterranean conditions in the Italian Peninsula. Italian Journal of Forest and Mountain Environment 65: 481-504. - doi: 10.4129/ifm.2010.5.02

Lombardi F, Cocozza C, Lasserre B, Tognetti R, Marchetti M (2011). Dendrochronological assessment of time-since-death in the old-growth Magellan's beech forest of Navarino Island (Chile). Austral Ecology 36: 329-340. - doi: 10.1111/j.1442-9993.2010.02154.x

Lombardi F, Lasserre B, Chirici G, Tognetti R, Marchetti M (2012). Deadwood occurrence and forest structure as indicators of old-growth forest conditions in Mediterranean mountainous ecosystems. Ecoscience 19: 344-355. - doi: 10.2980/19-4-3506

McCune B, Mefford MJ (2006). PC-ORD Multivariate analysis of ecological data (Version 5.10). MjM Software, Gleneden Beach, Oregon, USA.

Mackensen J, Bauhus J, Webber E (2003). Decomposition rates of coarse woody debris - a review with particular emphasis on Australian tree species. Australian Journal of Botany 51: 27-37. - doi: 10.1071/BT02014

Marchetti M, Lombardi F (2006). Analisi qualiquantitativa del legno morto in soprassuoli non gestiti: Il caso di "Bosco Pennataro", Alto Molise [Quali-quantitative analyses of deadwood in unmanaged stand: "Bosco Pennataro", Alto Molise]. Italian Journal of Forest and Mountain Environment 4: 275-302. [in Italian] - doi: 10.4129/IFM.2006.4.03

Marchetti M, Tognetti R, Lombardi F, Chiavetta U, Palumbo G, Sellitto $M$, Colombo $C$, lovieno $P$, Alfani A, Baldantoni D, Barbati A, Ferrari B, Bonacquisti S, Capotorti G, Copiz R, Blasi C (2010). Ecological portrayal of old-growth forests and persistent woodlands in the Cilento and Vallo di Diano National Park (southern Italy). Plant Biosystems 144: 130-147. - doi: 10.1080/11263500903560470

Marinšek A, Šilc U, Carni A (2013). Geographical and ecological differentiation of Fagus forest vegetation in SE Europe. Applied Vegetation Science 16: 131-147. - doi: 10.1111/j.1654-109X.20 12.01203.x

Martin F, Nehls U (2009). Harnessing ectomycorrhizal genomics for ecological insights. Current Opinion in Plant Biology 12: 508-515. - doi: 10.1016/j.pbi.2009.05.007

Mazzoleni S, Loporto A, Blasi C (1992). Multivariate analysis of climate patterns of the Mediterranean basin. Vegetatio 98: 1-12. - doi: 10.1007/BFo0031632

Müller J, Engel H, Blaschke M (2007). Assemblages of wood-inhabiting fungi related to silvicultural management intensity in beech forests in southern Germany. European Journal of Forest Research 126: 513-527. - doi: 10.1007/s10342007-0173-7

Nocentini S (2009). Structure and management of beech (Fagus sylvatica L.) forests in Italy. iForest 2: 105-113. - doi: 10.3832/iforo499-002
Nordén B, Paltto H (2001). Wood-decay fungi in hazel wood: species richness correlated to stand age and dead wood features. Biological Conservation 101: 1-8. - doi: 10.1016/S0006-3207 (01)00049-0

Nordén B, Ryberg M, Götmark F, Olausson B (2004). Relative importance of coarse and fine woody debris for the diversity of wood-inhabiting fungi in temperate broadleaf forests. Biological Conservation 117: 1-10. - doi: 10.1016/So0 06-3207(03)00235-0

Nordén B, Paltto H, Götmark F, Kjell W (2007). Indicators of biodiversity, what do they indicate? - Lessons for conservation of cryptogams in oak-rich forest. Biological Conservation 135: 369-379. - doi: 10.1016/j.biocon.2006.10.007 Odor P, Heilmann-Clausen J, Christensen M, Aude E, van Dort KW, Piltaver A, Siller I, Veerkamp MT, Walleyn R, Standovár T, van Hees AFM, Kosec J, Matočec N, Kraigher $\mathrm{H}$, Grebenc $\mathrm{T}$ (2001). Diversity and composition of dead wood inhabiting fungal and bryophyte communities in semi-natural beech forests in Europe. Nat-Man Working, Report 31, Nat-Man Project, Forest \& Landscape, University of Copenhagen, Denmark, pp. 60. [online] URL: http://curis.ku. dk/ws/files/49944671/working_report_31.pdf

Ódor P, Heilmann-Clausen J, Christensen M, Aude E, van Dort KW, Piltaver A, Siller I, Veerkamp MT, Walleyn R, Standovár T, van Hees AFM, Kosec J, Matočec N, Kraigher $\mathrm{H}$, Grebenc $\mathrm{T}$ (2006). Diversity of dead wood inhabiting fungi and bryophytes in semi-natural beech forests in Europe. Biological Conservation 131: 58-71. - doi: 10.1016/j.biocon.2006.02.004

Ogura-Tsujita Y, Gebauer G, Hashimoto T, Umata H, Yukawa T (2009). Evidence for novel and specialized mycorrhizal parasitism: the orchid Gastrodia confusa gains carbon from saprotrophic Mycena. Proceedings of the Royal Society B 276: 761-767. - doi: 10.1098/rspb.2008.1225 Paoletti E, Tuovinen J-P (2011). COST Action FP0903: research, monitoring and modelling in the study of climate change and air pollution impacts on forest ecosystems. iForest 4: 160161. - doi: 10.3832/iforo583-004

Parfitt D, Hunt J, Dockrell D, Rogers HJ, Boddy L (2010). Do all trees carry the seeds of their own destruction? PCR reveals numerous wood decay fungi latently present in sapwood of a wide range of angiosperm trees. Fungal Ecology 3: 338-346. - doi: 10.1016/j.funeco.2010.02.001 Penttilä R, Siitonen J, Kuusinen M (2004). Polypore diversity in managed and old-growth boreal Picea abies forests in southern Finland. Biological Conservation 117: 271-283. - doi: 10.1016/j. biocon.2003.12.007

Penman J, Gytarsky M, Hiraishi T, Krug T, Kruger D, Pipatti R, Buendia L, Miwa K, Ngara T, Tanabe $K$, Wagner $F$ (2003). Good practice guidance for land use, land-use change and forestry. Intergovernmental Panel on Climate Change, IPCC National Greenhouse Gas Inventories Programme, Kamiyamaguchi Hayama, Kanagawa, Japan, pp. 590. [online] URL: http:// www.ipcc-nggip.iges.or.jp/public/gpglulucf/gp glulucf_files/GPG_LULUCF_FULL.pdf Persiani AM, Audisio $P$, Lunghini $D$, Maggi $O$, Granito VM, Biscaccianti AB, Chiavetta U, Marchetti M (2010). Linking taxonomical and functional biodiversity of saproxylic fungi and 
beetles in broad-leaved forests in southern Italy with varying management histories. Plant Biosystems 144: 250-261. - doi: 10.1080/11263500 903561114

Peterken GF (1996). Natural woodland. ecology and conservation on northern temperate regions. Cambridge University Press, Cambridge, UK, pp. 522. [online] URL: http://books.google. com/books?id=p3y43NnvXPYC

Pouska V, Svoboda M, Leps ová A (2010). The diversity of wood-decaying fungi in relation to changing site conditions in an old-growth mountain spruce forest, Central Europe. European Journal of Forest Research 129: 219-231. doi: 10.1007/s10342-009-0324-0

Renvall P (1995). Community structure and dynamics of wood-rotting Basidiomycetes on decomposing conifer trunks in northern Finland. Karstenia 35: 1-51.

Rivas-Martìnez S, Diaz TE, Fernandez-Gonzalez F, Izco J, Loidi J, Lousa M (2002). Vascular plant communities of Spain and Portugal. Itinera Geobotanica 15: 1-2.

Rosati L, Di Pietro R, Blasi C (2005). La vegetazione forestale della regione temperata del "Flysch del Cilento" (Italia meridionale) [The woodlands of Temperate Region of "Flysch substrates in Cilento" (Southern Italy)]. Fitosociologia 42: 33-65. [in Italian]

Saitta A, Bernicchia A, Gorjón SP, Altobelli E, Granito VM, Losi C, Lunghini D, Maggi O, Medardi G, Padovan F, Pecoraro L, Vizzini A, Persiani AM (2011). Biodiversity of wood-decay fungi in Italy. Plant Biosystems 145: 958-968. doi: $10.1080 / 11263504.2011 .633114$

Schwarze FWMR (2007). Wood decay under the microscope. Fungal Biology Review 21: 133-170. - doi: 10.1016/j.fbr.2007.09.001

Siitonen J (2001). Forest management, coarse woody debris and saproxylic organisms: Fennoscandian boreal forests as an example. Ecological Bulletins 49: 11-41. [online] URL: http:// www.jstor.org/stable/20113262

Simard SW, Perry DA, Jones MD, Myrold DD, Durall DM, Molina R (1997). Net transfer of carbon between ectomycorrhizal tree species in the field. Nature 388: 579-582. - doi: 10.1038/415 57

Singh M, Khatoon S, Singh S, Kumar V, Rawat AK, Mehrotra S (2010). Antimicrobial screening of ethnobotanically important stem bark of medicinal plants. Pharmacognosy Research 2: 254-257. - doi: 10.4103/0974-8490.75456

Sippola AL, Renvall P (1999). Wood-decomposing fungi and seed-tree cutting: a 40-year perspective. Forest Ecology and Management 115: 183-201. - doi: 10.1016/S0378-1127(98)00398-3

Sippola $A L$, Similä $M$, Mönkkönen $M$, Jokimäki J (2004). Diversity of polyporous fungi (Polyporaceae) in northern boreal forests: effects of forest type and logging intensity. Scandinavian Journal of Forest Research 19: 152-163. - doi: 10.1080/02827580410026294

Spies TA (2004). Ecological concepts and diversity of old-growth forests. Journal of Forestry 102: 14-20. [online] URL: http://www.ingenta connect.com/content/saf/jof/2004/00000102/0 $0000003 /$ arto0007

Stokland JN, Siitonen J, Jonsson BG (2012). Biodiversity in dead wood. Cambridge University Press, Cambridge, UK, pp. 524.

Tabacchi G, Di Cosmo L, Gasparini P (2011). Aboveground tree volume and phytomass prediction equations for forest species in Italy. European Journal of Forest Research 130 (6): 911934. - doi: 10.1007/s10342-011-0481-9

Tognetti R, Marchetti M (2006). Influenza dei cambiamenti d'uso del suolo e delle strategie di gestione del bosco sull'allocazione del carbonio nel suolo negli ecosistemi forestali [Influence of land use changes and silvicultural management strategies on soil carbon allocation in forest ecosystems]. Italia Forestale e Montana 61: 5-51. [in Italian]
Vitale M, Mancini M, Matteucci G, Francesconi F, Valenti R, Attorre F (2012). Model-based assessment of ecological adaptations of three forest tree species growing in Italy and impact on carbon and water balance at national scale under current and future climate scenarios. iForest 5: 235-246. - doi: 10.3832/iforo634-005

Whalley AJS (1996). The xylariaceous way of life. Mycological Research 100: 897-922. - doi: 10.10 16/So953-7562(96)80042-6

Wirth C, Messier C, Bergeron Y, Frank D, Fankhänel A (2009). Old-growth forests definitions: a pragmatic view. In: "Old-growth forests: Function, fate and value" (Wirth C, Gleixner G, Heimann M eds.). Ecological Studies 207, Springer-Verlag, Berlin, Germany, pp. 11-33. Woodall CW, Westfall JA (2009). Relationships between the stocking levels of live trees and dead tree attributes in forests of the United States. Forest Ecology and Management 258: 2602-2608. - doi: 10.1016/j.foreco.2009.09.018

Wubet T, Christ S, Schöning I, Boch S, Gawlich M, Schnabel B, Fisher M, Buscot F (2012). Differences in soil fungal communities between European Beech (Fagus sylvatica L.) dominated forests are related to soil and understory vegetation. PLoS ONE 7 (e47500) 1-14. - doi: 10.1371/ journal.pone.0047500

Xu JT, Fan L (2001). Cytodifferentiation of the seeds (protocorms) and vegetative propagation corms-colonized by mycorrhizal fungi. Acta Botanica Sinica 43: 1003-1010. [online] URL: http://en.cnki.com.cn/Article_en/CJFDTOTALZWXB200110001.htm

\section{Supplementary Material}

Appendix 1 - The complete list of fungal species.

Link: Persiani_1304@supplo01.pdf 